\title{
EFFECT OF SIX WOOD EXTRACTS FROM FAMILY MELIACEAE AGAINST Psammotermes hybostoma (DESNEUX) (ISOPTERA: RHIMOTERMITIDAE). A - EFFECT OF WINTER WOOD EXTRACTS Sayed, R. M. M. ${ }^{\star}$ and Hoda M. Abdel Wahab** \\ * Forestry Dept. Hort. Res. Ins., Agric. Res. Centre, Giza \\ ** Zoology Dept., Fac. of Science, Aswan Univ.
}

\begin{abstract}
This study aimed to study the toxic effects of wood extracts from some timber trees belong to Family Meliaceae against Psammotermes hybostoma at the Tropical Farm, Aswan Botanical Garden and Faculty of Science, Aswan Univ. during winter 2011 and 2012. The meliaceous trees were Khaya senegalensis, K. ivorensis, Swietenia mahagoni, S. macrophylla, Azadirachta indica and Melia azedarach. Results pointed out that $S$. macrophylla followed by $A$. indica produced the highest values of total extractives while, $M$. azedarach produced the lowest one in the two seasons. Using water as a solvent produced the highest values of all wood extractives compared to the other solvents. Moreover, increasing concentrations of the different wood extracts up to $350 \mathrm{mg} / \mathrm{l}$ in winter resulted in a gradual increasing of mortality percentage for the $3^{\text {rd }}$ instars of termite. Using alcohol + benzene as a solvent extract for $K$. senegalensis followed by $M$. azaderach caused the highest values of mortality percentage for $P$. hybostoma compared to the other wood extracts. On the other hand, wood extract by benzene alone for $M$. azaderach followed by $K$. senegalensis led to the most toxic effects, while $S$. mahogany benzene extract led to the lowest one compared to the other treatments. According to LC 90 and LC 50 values, results revealed that alcohol + benzene extract or benzene alone of the tested trees at 300 and $150 \mathrm{ppm}$, respectively was highly toxic to $P$. hybostoma $3^{\text {rd }}$ instars worker.
\end{abstract}

Keywords: Wood Extracts, Family Meliaceae, Termite, Toxic Effects.

\section{INTRODUCTION}

The six successful woody trees widely grown in Egypt are Khaya senegalensis, K. ivorensis, Swietenia mahagoni, S. macrophylla, Azadirachta indica and Melia azedarach which belong to Family Meliaceae, which are high quality timber species (mahogany group), many uses for this wood from the fact that it combines such desirable characteristics as attractive appearance, good dimensional stability, excellent finishing qualities, and a high degree of natural durability. These valuable trees contain certain components which have some biological activity as insect's antifeedant (Nakatani et al., 2000) against several insects. Moreover, phytochemical analysis as crude methanolic seed extract of Khaya species will be used for preliminary qualitative screening of phytochemicals such as alkaloids, flavonoids, glycosides, lignins, phenols, saponins, sterols, terpenes and tannins (Sumitra et al., 2006).

Extractives are the compounds present in trees that can be extracted by organic solvents. They are found in higher concentrations in the bark of most woods and are generally considered to be biosynthesized in order to slow or 
prevent pathogen invasion. Their production is under strict genetic control, and some individual compounds are limited to individual species. Such compounds are broadly classified as secondary metabolites. Feeding damage and transmission of plant diseases by sucking insects and mites are some of the major causes of crop loss worldwide. Estimation on a world scale suggests that elimination of insect pests would increase crop production by about one third (Soliman, 2006). On the other hand, the lack of novel insecticides, the high cost of synthetic pyrethroids, environment and food safety concerns the unacceptability and toxicity of many organophosphates and organochlorines, and increasing insecticide resistance on a global scale are prompting some researchers to reconsider botanical insecticides in their search to address some of these problems.

Subterranean termites are the most destroyers in arid and semi- arid ecosystems (Krishmo, 1989). The sand termite, Psammotermes hybostoma (Desneux) is considered a serious pest in Aswan Province (Risk et al., 1982, Abdel Wahab and Rizk, 1998 and Abdel Wahab et al., 1998). Termites mostly feed on dead plant material, generally in the form of wood, leaf litter, soil or animal dung, and many species of termites are economically significant as pests that can cause serious structural damage to buildings, crops or plantation forests (Shaalan et al., 2006). The various effects of the extractives on these insects included, attractively, repellence, toxicity, stimulation or inhibition of feeding and growth (Carter, 1976 and Hanif et al., 1988). Therefore, this study was designed to examine the effects of winter wood extracts for some Meliaceae trees against Psammotermes hybostoma (Desneux).

\section{MATERIALS AND METHODS}

This study was carried out at the Tropical Farm, Kom- Ombo, Aswan Botanical Garden, Hort. Res. Inst., Agric.Res. Center and Zoology Dept., Fac. of Science Aswan Univ. during the seasons of 2011 and 2012 to study the effect of wood extracts of some tree species on Psammotermes hybostoma termite.

\section{1-Botanical Extracts:}

\section{1-1. Wood species:}

Six wood tree species i.e. Khaya senegalensis, K. ivorensis, Swietenia mahagoni, S. macrophylla, Azadirachta indica, and Melia azedarach at age of 15 were investigated in the present study.

\section{1-2. Extraction technique:}

Wood samples from the main branches (at least $10 \mathrm{~cm}$ in diameter) in the winter $\left(15^{\text {th }}\right.$ January) were dried at $70^{\circ} \mathrm{C}$ and milled then ground with $40-$ 60 mech. Three solvent were used i.e., Ethyl alcohol + benzene (1:2 by volume) for $4 \mathrm{~h}$. wood residue were air dried then extracted by Benzene for 4 $\mathrm{h}$. Wood residues were air dried then extracted by water for $4 \mathrm{~h}$. according to ASTM D- 1107 - 56 (1989). Wood sample were weighed before and after each extraction then each was calculated as percentage of wood in both seasons. 
2-Termite species:

Psammotermes hybostoma termite was used in the present study. These termites are abundant in arid and semi- arid regions of Upper Egypt, and the highly infested places are those of high moisture content.

Collection and preparation for tests: $P$. hybostoma individuals were collected from several cardboard baits buried in the Saddaka, El- Shallal district, Aswan Province, Egypt. The termite colony was kept in a large plastic container for three months. The container was filled with corsage cardboard as termite feeding. One day prior to test termite workers as externally undifferentiated insects beyond the $3^{\text {rd }}$ instars were counted (50 individuals) and transferred to the test plastic container and starved for $24 \mathrm{~h}$. before the test.

\section{3-Bioassay:}

\section{Preliminary screening and toxicological tests:}

For testing termite workers in both preliminary and LC 50 investigations, a stock solution of crude extract was prepared at $1 \mathrm{gm}$ in $10 \mathrm{ml}$ of absolute ethyl alcohol $(100.000 \mathrm{ml} / \mathrm{l})$ and required concentrations were prepared in ethyl alcohol for preliminary screening and toxicological tests. Crude extracts were screened at descending series of concentrations $(10,50,100,200$ and $300 \mathrm{mg} / \mathrm{l})$ to determine the LC 50 .

Extracts that caused $100 \%$ mortality at $200 \mathrm{ppm}$ were only selected and permitted for testing at the next concentration and so on. Termite workers were subjected to different concentration (at least five concentrations) of crude botanical extracts (paper pads treated with each conc.) fixed in plastic containers to determine LC 50. About 50 healthy workers beyond the $3^{\text {rd }}$ instars were starved for $24 \mathrm{~h}$. before testing and released into plastic containers containing $50 \mathrm{gm}$ sterile sand and $1 \mathrm{ml}$ distilled water. Containers were incubated at room temperature and mortality percent was recorded after $24 \mathrm{~h}$. Abbott's formula (1925) was used to correct mortality percentage if the control mortality percent was between 5 and $20 \%$.

4-Statistical analysis:

Data analysis was performed using ANOVA according to Snedecor (1965), and L.S.D. mentioned by Little and Hills (1978). The probate analysis statistical method and Litchified and Wilcoxon (1949) was used to calculate the logarithmic concentration probate line (LC- P lines) and the medium lethal concentration (LC 50), also the high lethal concentration (LC 90) values for each tested extracts.

\section{RESULTS}

\section{1 - Wood extracts:}

Obtained data in Table (1) illustrate that the mean values of winter wood extract percentages of 2011 and 2012 for the studied trees as affected by alcohol and benzene, benzene and water as solvents. This study has shown that the differences between meliaceous trees were significant and the highest extract percentages in wood can be obtained by S. macrophylla in the two seasons. Also, there were significantly differences between the solvents 
used and the values of wood extract percentages for the studied trees were increased due to using water as a solvent compared to the other applied solvents. Meanwhile, using benzene alone as a solvent resulted in the lowest values of wood extract percentage in the two seasons.

Table (1): Wood extract percentages for six species of family Meliaceae in the two seasons of 2011 and 2012.

\begin{tabular}{|l|c|c|c|c|c|c|c|c|}
\hline \multirow{2}{*}{ Species } & \multicolumn{4}{c|}{ Wood extract (\%) by 3 different solvents } \\
\cline { 2 - 8 } & \multicolumn{3}{|c|}{ First season (2011) } & \multicolumn{3}{c|}{ Second season (2012) } \\
\cline { 2 - 8 } & $\begin{array}{c}\text { Alcohol } \\
\& \\
\text { benzen }\end{array}$ & Benzene & Water & $\begin{array}{c}\text { Total } \\
\text { extract }\end{array}$ & $\begin{array}{c}\text { Alcohol } \\
\text { \& } \\
\text { benzene }\end{array}$ & Benzene & Water & $\begin{array}{c}\text { Total } \\
\text { extract }\end{array}$ \\
\hline Khaya senegalensis & 2.25 & 0.59 & 2.29 & 5.13 & 2.10 & 0.55 & 2.13 & 4.78 \\
K. ivorensis & 1.32 & 0.54 & 3.36 & 5.22 & 1.25 & 0.51 & 3.18 & 4.94 \\
Azadirachta indica & 2.92 & 0.28 & 2.69 & 5.89 & 2.77 & 0.26 & 2.52 & 5.55 \\
Melia azedarach & 1.14 & 0.25 & 1.76 & 3.15 & 1.07 & 0.24 & 1.63 & 2.94 \\
Swietenia mahagoni & 1.58 & 0.61 & 3.31 & 5.50 & 1.49 & 0.57 & 3.14 & 5.20 \\
S.macrophylla & 2.68 & 0.69 & 2.72 & 6.09 & 2.53 & 0.65 & 2.57 & 5.75 \\
\hline L.S.D. at 1 \% & 0.60 & 0.12 & 0.25 & 0.66 & 0.58 & 0.12 & 0.16 & 0.61 \\
\multicolumn{1}{|c|}{ at 5 \% } & 0.42 & 0.08 & 0.17 & 0.46 & 0.41 & 0.08 & 0.12 & 0.43 \\
\hline
\end{tabular}

2 - Preliminary screening of the wood extracts in winter against $P$. hybostoma:

Table (2) shows that the preliminary screening of different crude wood extracts against $3^{\text {rd }}$ instars of $P$. hybostoma. It indicated that increasing concentrations of the different crude winter wood extracts resulted in gradual increases of mortality percentage for the $3^{\text {rd }}$ instars of termite. However, 10 and $50 \mathrm{mg} / \mathrm{l}$ concentrations were the lowest effective for all the tree species, while 300 and $350 \mathrm{mg} / \mathrm{l}$ were the most effective treatments when compared to the other treatments. A. indicia, S. mahagoni and K. senegalensis alcohol+ benzene extracts at $250 \mathrm{mg} / \mathrm{l}$ were the most effective treatments, compared to the other tree species at the same concentrations. Water extract for all tree species was not effective on the $3^{\text {rd }}$ instars of $P$. hybostoma.

Table (2): Preliminary screening of different crude winter wood extracts against $3 \mathrm{ed}$ instars individuals of Psammoterms hybostoma (24 hr)

\begin{tabular}{|c|c|c|c|c|c|c|c|c|c|}
\hline \multirow{2}{*}{$\begin{array}{l}\text { Winter wood } \\
\text { extracts }\end{array}$} & \multirow{2}{*}{ Extraction solvent } & \multicolumn{8}{|c|}{ Mortality (\%) at concentration mg/ I } \\
\hline & & 10 & 50 & 100 & 150 & 200 & 250 & 300 & 350 \\
\hline \multirow{2}{*}{$\begin{array}{l}\text { Khaya } \\
\text { Senegalensis }\end{array}$} & Alcohol\&benzene & 1 & 4 & 15 & 17 & 25 & 66 & 84 & 100 \\
\hline & Benzene & 2 & 7 & 8 & 9 & 13 & 38 & 73 & 100 \\
\hline \multirow{2}{*}{ K. ivorensis } & Alcohol\&benzene & 2 & 9 & 22 & 24 & 39 & 44 & 98 & 100 \\
\hline & Benzene ext. & 1 & 3 & 21 & 22 & 34 & 35 & 81 & 100 \\
\hline \multirow{2}{*}{ Azadirachta indica } & Alcohol\&benzene & 0 & 12 & 23 & 28 & 36 & 68 & 82 & 100 \\
\hline & Benzene & 0 & 9 & 28 & 37 & 45 & 63 & 79 & 100 \\
\hline \multirow{2}{*}{ Melia azaderach } & Alcohol\&benzene & 0 & 6 & 13 & 25 & 36 & 49 & 98 & 100 \\
\hline & Benzene & 0 & 6 & 10 & 13 & 28 & 37 & 71 & 100 \\
\hline \multirow{2}{*}{$\begin{array}{l}\text { Swietenia } \\
\text { mahagoni }\end{array}$} & Alcohol\&benzene & 0 & 6 & 17 & 21 & 42 & 65 & 95 & 100 \\
\hline & Benzene & 0 & 2 & 10 & 12 & 33 & 56 & 88 & 100 \\
\hline \multirow{2}{*}{ S. macrophylla } & Alcohol\&benzene & 0 & 8 & 11 & 14 & 18 & 41 & 86 & 100 \\
\hline & Benzene & 0 & 3 & 8 & 9 & 17 & 38 & 77 & 100 \\
\hline \multirow{3}{*}{ Control } & Alcohol\&benzene & 0 & 0 & 3 & 12 & 5 & 17 & 18 & 25 \\
\hline & Benzene & 0 & 0 & 1 & 3 & 7 & 8 & 13 & 20 \\
\hline & Water & 0 & 0 & 0 & 0 & 0 & 0 & 0 & 0 \\
\hline
\end{tabular}




\section{3 - Toxicity of winter wood extract by alcohol and benzene:}

Results of toxicity and mortality percentage of winter wood extract by alcohol and benzene tested against $3^{\text {rd }}$ instars of $P$. hybostoma were presented in Table (3). The tested trees were significantly differed in their toxicity and mortality percentage. However, the highest mortality percentage was recorded with $K$. senegalensis, while, using $S$. macrophylla extract resulted in the lowest one. On the other hand, toxicity and mortality percentage were significantly affected by the used concentrations. The increasing of concentration resulted in highly significant increasing in the mortality percentage. In relation to the interaction between the used woody trees and extract concentrations, it is evident that, using $300 \mathrm{ppm}$ of $K$. ivorensis, $M$. azaderach and $K$. senegalensis significantly increased mortality percentage when compared to the other interactions.

Table (3): Toxicity and mortality percentage of winter wood extracts by alcohol \& benzene against $3^{\text {rd }}$ instar of $P$. hybostoma

\begin{tabular}{|c|c|c|c|c|c|c|c|}
\hline \multirow[b]{2}{*}{ Wood extracts } & \multicolumn{7}{|c|}{ Concentration ( ppm ) } \\
\hline & 50 & 100 & 150 & 200 & 250 & 300 & $\begin{array}{l}\text { Mean } \\
\text { (A) }\end{array}$ \\
\hline Khaya senegalensis & 14.25 & 26.25 & 37.75 & 60.25 & 82.00 & 92.75 & 52.21 \\
\hline K. ivorensis & 7.00 & 16.50 & 35.50 & 54.50 & 86.75 & 95.00 & 49.20 \\
\hline Azadirachta indica & 5.75 & 16.00 & 43.75 & 59.25 & 70.50 & 89.50 & 47.46 \\
\hline Melia azaderach & 15.25 & 26.75 & 37.00 & 56.75 & 68.50 & 94.50 & 49.79 \\
\hline Swietenia mahagoni & 11.25 & 17.00 & 38.00 & 51.75 & 66.25 & 71.75 & 42.67 \\
\hline S. macrophylla & 13.25 & 28.50 & 36.00 & 44.00 & 50.00 & 64.25 & 39.33 \\
\hline Mean (B) & 11.13 & 21.83 & 38.00 & 54.42 & 70.67 & 84.63 & \\
\hline 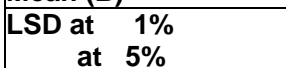 & $\begin{array}{l}A: 5.11 \\
A: 3.70\end{array}$ & $\begin{array}{l}\text { B : } \\
\text { B : }\end{array}$ & & $\begin{array}{c}A B: 8.3 \\
A B: 3.4\end{array}$ & & & \\
\hline
\end{tabular}

$A=$ Wood extracts $B=$ Concentration (ppm) $A B=$ interaction

\section{4 - Toxicity of winter wood extracts by benzene:}

Significant increases were observed in mortality percentage for $P$. hybostoma instars due to applying the different wood extract treatments. The highest values of mortality percentage $(53.58 \%)$ resulted from using $M$. azaderach extract against $3^{\text {rd }}$ instars of $P$. hybostoma (Table, 4). Concerning the general effect of the tested concentrations on the $3^{\text {rd }}$ instars of $P$. hybostoma regardless of tree species, it is obvious that the differences between concentrations effect were significant. The highest value $(78.79 \%)$ of mortality percentage resulted from using $300 \mathrm{ppm}$, and the lowest one $(11.46 \%)$ was with $50 \mathrm{ppm}$. In regard to the interaction between tree species and the used concentrations on mortality percent of $P$. hybostoma, it was significant. Maximum mortality $(94.00 \%)$ was recorded in $300 \mathrm{ppm}$ of $K$. ivorensis, while the lowest mortality was recorded with $50 \mathrm{ppm}$ of $A$. indica $(6.0 \%)$. 
Table (4): Toxicity and mortality percentage of winter wood extract by benzene against $3^{\text {rd }}$ instars of $P$. hybostoma.

\begin{tabular}{|l|c|c|c|c|c|c|c|}
\hline \multirow{2}{*}{ Wood extracts } & \multicolumn{7}{|c|}{ Concentration (ppm ) } \\
\cline { 2 - 8 } & 50 & 100 & 150 & 200 & 250 & 300 & Mean (A) \\
\hline Khaya senegalensis & 11.50 & 20.25 & 36.50 & 60.25 & 84.50 & 93.75 & 51.13 \\
\hline K. ivorensis & 8.75 & 22.75 & 34.00 & 47.25 & 75.50 & 94.00 & 47.04 \\
\hline Azadirachta indica & 6.00 & 17.25 & 39.25 & 56.75 & 71.00 & 88.75 & 46.50 \\
\hline Melia azaderach & 21.25 & 36.00 & 45.50 & 56.00 & 69.50 & 93.25 & 53.58 \\
\hline Swietenia mahagoni & 9.50 & 15.50 & 25.00 & 29.25 & 35.50 & 40.75 & 25.92 \\
\hline S. macrophylla & 11.75 & 32.25 & 35.50 & 42.00 & 53.25 & 62.25 & 39.50 \\
\hline Mean (B) & 11.46 & 24.00 & 35.96 & 48.58 & 64.88 & 78.79 & \\
\hline LSD at 1\% & $\mathrm{A}: 2.33$ & $\mathrm{~B}: 3.00$ & $\mathrm{AB}: 7.35$ \\
\multicolumn{1}{|c|}{ 5\% } & $\mathrm{A}: 1.68$ & $\mathrm{~B}: 1.24$ & AB $: 03$ \\
\hline
\end{tabular}

$A=$ Wood extracts $B=$ Concentration (ppm) $A B=$ interaction

\section{5 - Toxicity of winter wood extract by water:}

Mean mortality percentages for the $3^{\text {rd }}$ instars of $P$. hybostoma as affected by winter wood extracts are given in Table (5). The tested meliaceous trees up to $150 \mathrm{ppm}$ are not affective. Using water as solvent for $K$. senegalensis extract resulted in the highest values of mortality percentage for $P$. hybostoma compared to the other trees. Meanwhile, the lowest values of mortality resulted due to using water extract of $S$. macrophylla and $K$. ivorensis. According to the data shown in this table, application of $350 \mathrm{ppm}$ gave the highest value of mortality compared to the other concentrations. On the other hand, the combined effect of wood extract and the used concentration showed that the highest value of mortality percentage $(24 \%)$ was due to $M$. azaderach at $350 \mathrm{ppm}$.

Table (5): Preliminary screening of water plant extracts in winter by water against $3^{\text {rd }}$ instars individuals of Psammoterms hybostoma (24 hr)

\begin{tabular}{|l|c|c|c|c|c|c|c|c|}
\hline \multirow{2}{*}{ Water wood extracts } & \multicolumn{7}{|c|}{ Mortality (\%) at concentration (ppm) } \\
\cline { 2 - 11 } & 10 & 50 & 100 & 150 & 200 & 250 & 300 & 350 \\
\hline Khaya Senegalensis & 0 & 0 & 0 & 0 & 13 & 17 & 19 & 21 \\
\hline K. ivorensis & 0 & 0 & 0 & 0 & 1 & 3 & 4 & 13 \\
\hline Azadirachta indica & 0 & 0 & 0 & 0 & 5 & 8 & 10 & 12 \\
\hline Melia azaderach & 0 & 0 & 0 & 0 & 1 & 2 & 8 & 24 \\
\hline Swietenia mahagoni & 0 & 0 & 0 & 0 & 2 & 4 & 6 & 8 \\
\hline S. macrophylla & 0 & 0 & 0 & 0 & 0 & 1 & 4 & 5 \\
\hline Control & 0 & 0 & 0 & 0 & 0 & 0 & 0 & 0 \\
\hline
\end{tabular}

Toxicity of winter water extracts against the $3^{\text {rd }}$ instars of $P$. hybostoma is presented in Table (6). It is worthy to notice that the differences between meliaceous trees were significant. Maximum mortality $(45.83 \%)$ was obtained due to using $K$. senegalensis extract. On the other hand, using 800 ppm of water extract resulted in the highest value $(45.50 \%)$ of toxicity compared to the other concentrations. Data in this

table represented the combined effect of the woody extract and the tested concentrations; it was obvious that, there were significant differences between water extracts and their concentrations. Maximum mortality $(61.00$ $\%$ ) was recorded from using $800 \mathrm{ppm}$ of $K$. senegalensis water extract. 
Table (6): Toxicity and mortality percentage of winter wood extract by water against $3^{\text {rd }}$ instars of $P$. hybostoma.

\begin{tabular}{|l|c|c|c|c|c|c|c|}
\hline \multirow{2}{*}{ Wood extracts } & \multicolumn{7}{|c|}{ Concentration (ppm ) } \\
\cline { 2 - 9 } & 300 & 400 & 500 & 600 & 700 & 800 & Mean (A) \\
\hline Khaya senegalensis & 17.00 & 37.25 & 45.50 & 56.25 & 58.00 & 61.00 & 45.83 \\
\hline K. ivorensis & 3.00 & 15.50 & 18.75 & 22.50 & 31.75 & 37.25 & 21.50 \\
\hline Azadirachta indica & 5.75 & 12.75 & 23.00 & 26.50 & 30.00 & 34.00 & 22.00 \\
\hline Melia azaderach & 14.00 & 21.25 & 27.00 & 35.75 & 38.25 & 42.25 & 29.75 \\
\hline Swietenia mahagoni & 11.25 & 20.75 & 26.50 & 35.25 & 40.25 & 44.25 & 29.70 \\
\hline S. macrophylla & 15.00 & 31.00 & 37.00 & 44.50 & 51.50 & 54.25 & 38.88 \\
\hline Mean (B) & 11.04 & 23.08 & 29.63 & 36.79 & 41.63 & 45.50 & \\
\hline LSD at 1\% & $\mathrm{A}: 4.83$ & $\mathrm{~B}: 2.99$ & $\mathrm{AB}: 7.32$ \\
\multicolumn{7}{|c|}{ 5\% } & $\mathrm{AB}: \mathbf{1 . 2 3}: 3.02$ \\
\hline
\end{tabular}

$A=$ Wood extracts $B=$ Concentration (ppm) $A B=$ interaction

\section{$6-\mathrm{LC}_{30}, \mathrm{LC}_{50}, \mathrm{LC}_{90}$ and slope data of winter wood - alcohol + benzene extracts:}

Data shown in Table (7) represented LC 30, LC 50 and LC 90 values and slope data of winter plant- alcohol + benzene tested against $3^{\text {rd }}$ instars larva of Psammotermes hybostoma. According to LC 90 values data showed that, K. ivorensis, A. indica, M. azaderach, S. mahagoni, S. macrophylla and $K$. senegalensis alcohol + benzene extract $(300 \mathrm{ppm})$ was highly toxic to $P$. hybostoma 3rd instars worker. The slope values of LC 90 in $K$. senegalensis and $K$. ivorensis, alcohol + benzene extracts were the same (0.12 for each), also in $A$. indica and $M$. azaderach ( 0.11 for each) and in $S$. mahagoni and $S$. macrophylla ( 0.10 for each).

According to LC 50 values, Table (7) showed that, alcohol + benzene extract of the tested meliaceous trees was highly toxic against termite workers at $150 \mathrm{ppm}$. On the other hand, the highest slope value (18.22) of the tested trees was due to $M$. azaderach extract, while the lowest one $(0.10)$ resulted from S. macrophylla.

Table (7) : $\mathrm{LC}_{30}, \mathrm{LC}_{50}, \mathrm{LC}_{90}$ and slope data of winter wood - alcohol + benzene extracts against $3^{\text {rd }}$ instars larva of Psammotermes hybostoma

\begin{tabular}{|c|c|c|c|c|c|c|c|c|c|}
\hline \multirow{2}{*}{ Wood extracts } & \multicolumn{3}{|c|}{ L.C. 30} & \multicolumn{3}{|c|}{ L.C. 50} & \multicolumn{3}{|c|}{ L. C. 90} \\
\hline & p.p.m & $95 \%$ & Slop \pm S.E & p.p.m & $95 \%$ & Slop \pm S.E & p.p.m & $95 \%$ & Slop \pm S.E \\
\hline \begin{tabular}{|l|} 
Khaya \\
senegalensis
\end{tabular} & 100 & 30.26 & $\begin{array}{c}8.33 \pm \\
0.56\end{array}$ & 150 & 50.57 & $\begin{array}{c}11.41 \pm \\
0.95\end{array}$ & 300 & 60.00 & $\begin{array}{c}0.12 \pm \\
46176.64\end{array}$ \\
\hline K. ivorensis & 100 & 30.02 & $\begin{array}{c}10.59 \pm \\
0.74\end{array}$ & 150 & 50.17 & $\begin{array}{c}13.98 \pm \\
1.10\end{array}$ & 300 & 90.00 & $\begin{array}{c}0.12 \pm \\
46952.11\end{array}$ \\
\hline \begin{tabular}{|l|} 
Azadirachta \\
indica
\end{tabular} & 100 & 30.74 & $\begin{array}{c}6.75 \pm \\
0.46\end{array}$ & 150 & 50.26 & $\begin{array}{c}11.02 \pm \\
1.32\end{array}$ & 300 & 90.00 & $\begin{array}{c}0.11 \pm \\
44394.70 \\
\end{array}$ \\
\hline $\begin{array}{l}\text { Melia } \\
\text { azaderach }\end{array}$ & 100 & 30.08 & $\begin{array}{c}8.76 \pm \\
0.71\end{array}$ & 150 & 50.00 & $\begin{array}{c}18.22 \pm \\
2.53\end{array}$ & 300 & 90.00 & $\begin{array}{c}0.11 \pm \\
44659.48\end{array}$ \\
\hline \begin{tabular}{|l} 
Swietenia \\
mahagoni
\end{tabular} & 100 & 30.89 & $\begin{array}{c}5.46 \pm \\
0.44\end{array}$ & 150 & 50.32 & $\begin{array}{c}8.06 \pm \\
1.18\end{array}$ & 300 & 90.00 & $\begin{array}{c}0.10 \pm \\
35499.21\end{array}$ \\
\hline S. macrophylla & 100 & 30.68 & $\begin{array}{c}4.74 \pm \\
0.65\end{array}$ & 250 & 50.11 & $\begin{array}{c}0.10 \pm \\
0.25\end{array}$ & 300 & 90.00 & $\begin{array}{c}0.10 \pm \\
38906.62\end{array}$ \\
\hline
\end{tabular}


7 - $\mathrm{LC}_{30}, \mathrm{LC}_{50}, \mathrm{LC}_{90}$ and slope data of winter plant - benzene extracts:

Data in Table (8) indicated that, LC 50 values of the tested meliaceous trees benzene extract was highly toxic to termite (150 ppm). Also, LC 50 values of the trees were nearly similar (50.00). The highest slope values were obtained with $K$. ivorensis and $M$. azaderach (16.70 and 15.84, respectively) while; the lowest value (0.38) was obtained from S. mahagoni. According to LC 90 values of the tested trees, tabulated data pointed out that, benzene extract tested against 3rd larva of termite was highly toxic (300 ppm) and was similar (90.00). The slope values of $K$. ivorensis, $A$. indica and $M$. azaderach were typical (0.11), also $S$. mahagoni and $S$. macrophylla gave typical slope values $(0.10)$.

Table (8) : $\mathrm{LC}_{30}, \mathrm{LC}_{50}, \mathrm{LC}_{90}$ and slope data of winter plant - benzene extract against $3^{\text {rd }}$ instars larva of Psammotermes hybostoma .

\begin{tabular}{|c|c|c|c|c|c|c|c|c|c|}
\hline \multirow{2}{*}{ Wood extracts } & \multicolumn{3}{|c|}{ L.C. 30} & \multicolumn{3}{|c|}{ L.C. 50} & \multicolumn{3}{|c|}{ L. C. 90} \\
\hline & p.p.m & $95 \%$ & Slop \pm S.E & p.p.m & $95 \%$ & Slop \pm S.E & p.p.m & $95 \%$ & Slop \pm S.E \\
\hline $\begin{array}{l}\text { Khaya } \\
\text { senegalensis }\end{array}$ & 100 & 30.14 & $\begin{array}{c}9.02 \pm \\
0.58\end{array}$ & 150 & 50.55 & $\begin{array}{c}11.91 \pm \\
0.94\end{array}$ & 300 & 90.00 & $\begin{array}{c}0.12 \pm \\
40553.94\end{array}$ \\
\hline K. ivorensis & 100 & 30.00 & $\begin{array}{c}11.38 \pm \\
0.90\end{array}$ & 150 & 50.00 & $\begin{array}{c}16.70 \pm \\
1.57\end{array}$ & 300 & 90.00 & $\begin{array}{c}0.11 \pm \\
43582.78\end{array}$ \\
\hline $\begin{array}{l}\text { Azadirachta } \\
\text { indica }\end{array}$ & 100 & 30.37 & $\begin{array}{c}7.29 \pm \\
0.52\end{array}$ & 150 & 50.16 & $\begin{array}{c}11.56 \pm \\
1.32\end{array}$ & 300 & 90.00 & $\begin{array}{c}0.11 \pm \\
43435.19\end{array}$ \\
\hline \begin{tabular}{|l} 
Melia \\
azaderach
\end{tabular} & 100 & 30.90 & $\begin{array}{c}6.66 \pm \\
0.63\end{array}$ & 150 & 50.01 & $\begin{array}{c}15.84 \pm \\
2.16\end{array}$ & 300 & 90.00 & $\begin{array}{c}0.11 \pm \\
37369.47\end{array}$ \\
\hline $\begin{array}{l}\text { Swietenia } \\
\text { mahagoni }\end{array}$ & 200 & 30.81 & $\begin{array}{c}7.25 \pm \\
2.57\end{array}$ & 300 & 50.00 & $\begin{array}{c}0.38 \pm \\
0.69\end{array}$ & 300 & 90.00 & $\begin{array}{c}0.10 \pm \\
38430.50\end{array}$ \\
\hline S. macrophylla & 100 & 30.85 & $\begin{array}{c}4.52 \pm \\
0.65\end{array}$ & 200 & 50.08 & $\begin{array}{c}12.84 \pm \\
4.79\end{array}$ & 300 & 90.00 & $\begin{array}{c}0.10 \pm \\
38802.67\end{array}$ \\
\hline
\end{tabular}

\section{8 - $\mathrm{LC}_{30}$ and slope data of winter plant - water extracts:}

Results in Table (9) revealed that, water extracts of the tested woody trees were different in their effect on $P$. hybostoma as $K$. senegalensis and $S$. macrophylla were more effective ( $\mathrm{LC} 30=300$ and $350 \mathrm{ppm}$, respectively), while the slight effect $(\mathrm{LC} 30=700 \mathrm{ppm})$ was with $K$. ivorensis. The slope values were different among the six tree species extractives and the highest value (16.46) was obtained with $K$. ivorensis, while the lowest one (5.30) was with $K$. senegalensis.

Table (9): $\mathrm{LC}_{30}$ and slope data of winter plant - water extracts against $3^{\text {rd }}$ instars larva of Psammotermes hybostoma.

\begin{tabular}{|l|c|c|c|}
\hline \multicolumn{1}{|c|}{ Wood extracts } & \multicolumn{3}{c|}{ L.C. 30} \\
\cline { 2 - 4 } & ppm & $95 \%$ & Slop \pm S.E \\
\hline Khaya senegalensis & 300 & 30.97 & $5.30 \pm 0.37$ \\
\hline K. ivorensis & 700 & 30.95 & $16.46 \pm 10.14$ \\
\hline Azadirachta indica & 600 & 30.16 & $9.62 \pm 6.09$ \\
\hline Melia azaderach & 500 & 30.75 & $6.84 \pm 1.48$ \\
\hline Swietenia mahagoni & 500 & 30.79 & $7.46 \pm 1.44$ \\
\hline S. macrophylla & 350 & 30.65 & $5.83 \pm 0.58$ \\
\hline
\end{tabular}




\section{DISCUSSION}

Extracts are the compounds present in trees that can be extracted by water or organic solvents. They are found in higher concentrations in the bark and wood of most timber trees and are generally considered to be biosynthesized in order to slow or prevent pathogen invasion. Their production is under strict genetic control, and some individual compounds are limited to individual species. Such compounds are broadly classified as secondary metabolites. In this respect, this investigation confirmed the presence of these compounds and the toxic effects of meliaceous trees as botanical extracts on instars of $P$. hybostoma. However, there were differences in their effects as reported by Alfazairy et al. (1994); Badshah et al. (2004);Shaalan et al. ( 2006) and Olufemi et al. (2011). Also, mortality percentages due to the used wood extracts were significantly different from control, suggesting the toxic effect of this family against termites. The present study found that $S$. macrophylla and $A$. indica were superior in total extracts compared to the other trees. Moreover, toxicity and mortality percentages of winter wood extract by alcohol + benzene were superior to that of the other solvents. According to the results of sublethal concentrations (LC 30, LC 50 and LC 90) of the tested extracts, organic solvents were surprisingly better than water extract one. These results were in accordance with that of Alfazairy et al. (1994); Winks and Schimmer (1999) and Shaalan et al. (2006). Findings suggested that meliaceous wood extracts may produce larvicidal effects (behaving like general toxicants) against $P$. hybostoma. On the other hand, slope value for each of the tested extracts was quite different; which suggested the presence of different compounds and/ or sites of activity rather than differences in compound concentration.

\section{REFFERENCES}

Abbott, W.S. (1925): Methods for computing the effectiveness of an insecticide. J. Econ. Entoml., 18 (2): 265- 273.

Abdel Wahab, H.M. and M.A. Rizk (1998): The role of termites in destroying the wooden trees near Kima Factory, Aswan, Egypt. J. Egypt Ger. Soc. Zool., 65- 77 (8 th Int. Conf. 8- 11 Nov., 2000).

Abdel Wahab, H.M.; A.I. Hamed and N.A. Emary (1998): Antitermite principles isolated from the wild herb, Psoralia plicata Del. Ass. Univ. Ball. Environ. Res., 1 (2): 17- 25.

Alfazairy, A. A.; F.A. Hassan and A.M. Abd El- Dayem (1994): Insecticidal effect of three meliaceous seed oils against castes of the dry- wood termites, Kalotermis flavicollis Fabr. (Isoptera: Kalotermitidae). Proc. The first Conf. of Ornamental Hort. Vol. (2); 748- 762.

ASTM D- 1107- 56(American Society for Testing Materials (1989): Standard test methods for alcohol- benzene solubility of wood. ASTM D- 110756. Philadelphia, PA. 
Badshah, H.; Z. Salihah; A. Salijogi and M. Shakur (2004): Toxic effects of AK (Calotropis procera) plant extracts against termis (Heterotermes indicola and Coptotermes heimi) Isoptera: Rhinotermitidae. Pakistan J. Biol. Sci., 7 (9): 1603- 1606.

Carter, F.L.(1976): Responses of subterranean termites to wood extractives. Material and Organismen Beiheft, 3: 357- 365.

Hanif, G.; M.I. Ghadhury; M. Faroog and J. Rahmatullah (1988): Preliminary studies on antiermitic properties of common woods of Pakistan and their extractives. Pakistan J. of Forestry, 38: 167- 173.

Krishmo, K. (1989): Order Isoptera In: D.J.Borror; C.A.Triplehorn and N.F. Johnson (eds.) An Introduction to the Study of Insects. Saunders College Publishing, Philadeliphia, p. 234- 241.

Litchfield, J.T. and F. Wilcoxon (1949): A simplified method of evaluating dose- effect experiments. J. Pharmac. Exp. Ther 96. 99- 113.

Little, I. M. and F.J. Hills (1978): Agricultural Experimentation, Design and Analysis. Johan Wiely and Sons. Inc. New York.

Nakatani, M.; S.A.M. Abdelgaleil; H.Okamura; T.Iwagawa; A.Sato and M. Doe (2000): Khayanolides $A$ and $B$, new rearranged phragmalin limonoid antifeedants from Khaya senegalensis. Tetra. L.et. 41: (33), 6473- 6477.

Olufemi, A.S.; G.O. Yager; B.D. Zira and A. Usman (2011): Termiticidal effect of neem extracts on the wood of Khaya senegalensis. Research J. of Forestry, 5: 128- 138.

Rizk, M.A.; F.M. Khalil and A. M. Ali (1982): Assesment of damage due to termite in Egypt. 1. New Valley. Western desert. Assiut J. Agric. Sci., 13 (3): 93- 100.

Shaalan, E.A.; D.V. Canyon; H. Abdel- Wahab and A. Mansour (2006): Efficacy of eight larvicidal botanical extracts from Khaya senegalensis and Daucus carota against Culex annulirostris. J. of AmericanMosquito Control Association, 22(3): p.433 - 436.

Snedecor, G.W. (1965): Statistical Methods $5^{\text {th }}$ ed. lowa State College Press, Ames, lowa.

Soliman, M.M. (2006): Phytochemical and toxicological studies of Artemisia L. (compositae) essential oil against some insect pests. Acta Phytopathologica Hungarica, 41 (3 - 4), p. 395- 406.

Sumitra, C.; P. Jigna and K. Nehal (2006): Evaluation of antibacterial activity and phytochemical analysis of Bauhinia variegate L. bark. African Journal of Biomedicinal Research, 9: $53-56$.

Winks, M. and O. Schimmer (1999): Modes of action of defensive secondary metabolities. Function of plant MSs and their exploitation in biotechnology. Annual Plant Reviews, Vol. 3, p. 17- 133. 
تأثير مستخلصات ستة أنواع خثبية تابعة لعائلة الماهوجنى على النمل الأبيض

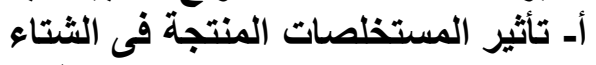

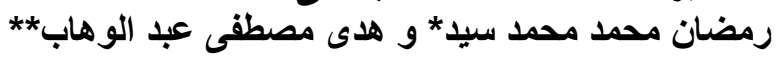

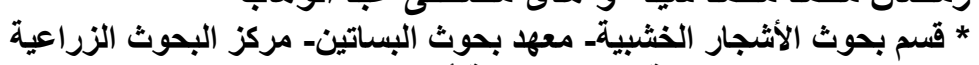

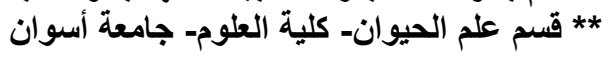

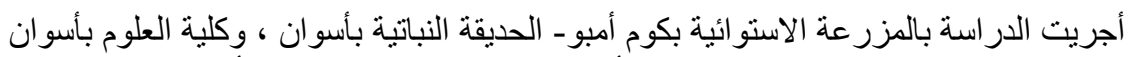

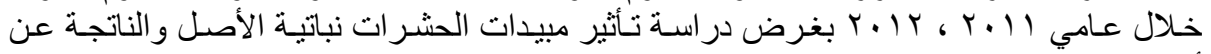

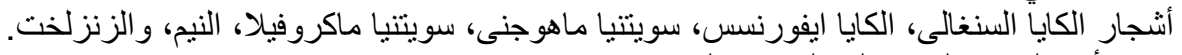

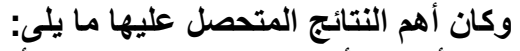

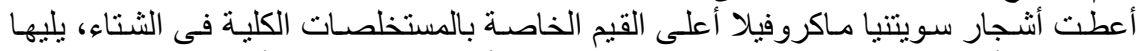

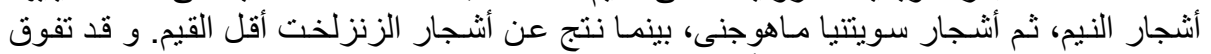

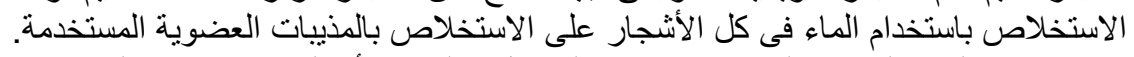

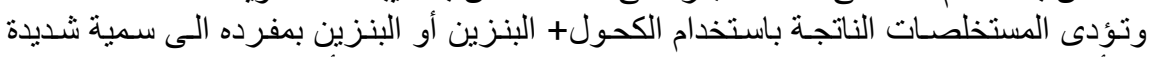

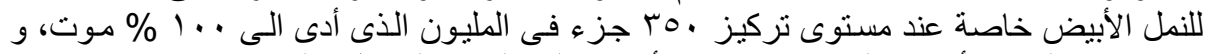

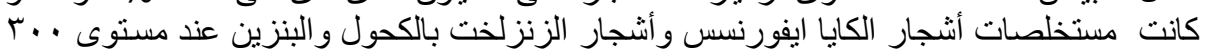

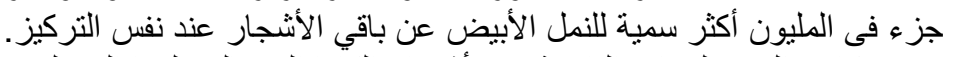

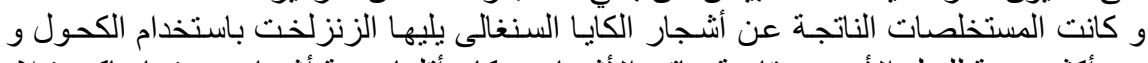

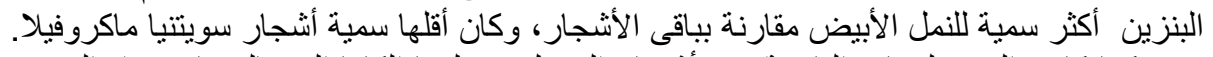

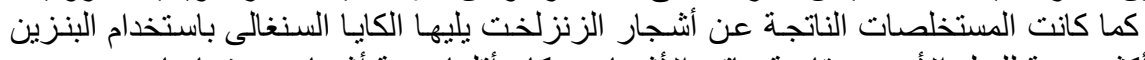

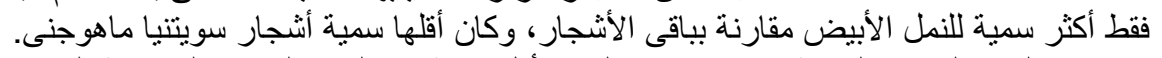

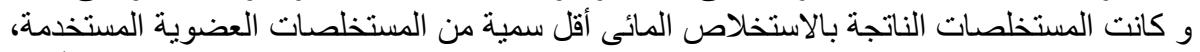

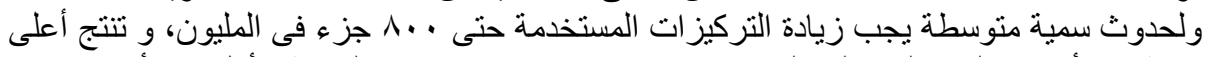
سمية عن أثجار الكايا السنغالى يليها سويتنيا ماكروفيلا، بينما تتتج السمية الأقل عن أثنجار كايا

بناء على قيم LC 90 LC 50 الخاصة بالاستخلاص باستخدام الكحول+ البنزين أو البنزين ايفورنس.

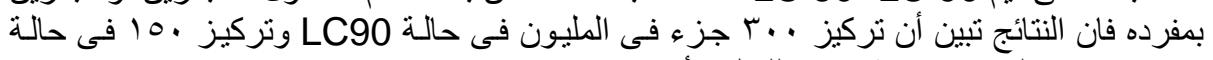

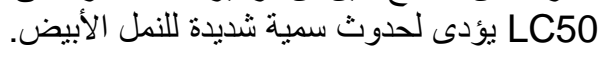

كلية الزراعة - جامعة المنصورة
قام بتحكيم البحث

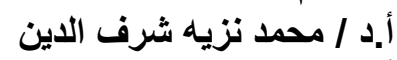

أ.د / صفوت لبيب مكسيموس ثنرف الاين 